\title{
Restriction analysis and differentiation of Ukrainian strains of infectious bursal disease virus
}

\author{
A. S. Pastyria ${ }^{1,2}$, I. O. Sobko ${ }^{2}$, V. P. Polischuk ${ }^{1}$ \\ ${ }^{1}$ Educational and Scientific Center "Institute of Biology", Taras Shevchenko National University of Kyiv \\ 64/13, Volodymyrska Str., Kyiv, Ukraine, 01601 \\ ${ }^{2}$ Center of Veterinary Diagnostics \\ 25-A, Ushinskogo stк., Kyiv, Ukraine \\ ann.pastyria@gmail.com
}

Infectious bursal disease virus (IBDV) had a great influence on poultry industry since emergence of very virulent strains in late $80^{\text {th }}$ of XX century. Virus leads to immunosuppression and high mortality. There are many different vaccines against IBDV, so characterization of field strains is needed. Aim. To characterize and differentiate vaccine and field virus strains using the method of restriction analysis. Methods. RNA was extracted using sorption method, carried reverse transcription was carries out and PCR was performed using specific primers to VP2 gene. Obtained amplicons were digested with a set of restriction enzymes MvaI, MboI, SspI, BspMI, SacI, BstEII. Results. During the study restriction profile of 8 vaccine strains have been described and 120 bursa samples from infected birds have been analyzed. Most of the analyzed virus isolates had restriction profiles similar to vaccine strains. Vaccine strains belonging to the same group in terms of attenuation had a similar restriction profile. Four field isolates have been classified as vvIBDV. They were differentiated from vaccine strains by presence of SspI and lack BstEII sites. Restriction analysis is appropriate to differentiate vaccine and field IBDV isolates. Conclusion. This approach can be used to monitor vvIBDV in poultry farms.

K e y w o r d s: IBDV, field strains, vvIBDV, restriction analysis.

\section{Introduction}

Since the first outbreak of infectious bursal disease (IBD) it became one of the main problems in poultry industry. The infectious bursal disease virus (IBDV) has been discovered in the area of Gumboro, Delaware, USA. Since
1962 the classical strains of the virus have been prevalent in North and South America. In 1986 in central Europe new virus strains appeared [1]. They induced $70 \%$ mortality of affected birds. During next 10 years such very virulent strains (vvIBDV) have been spread in Europe, Asia, Africa and South America. In

(C) 2017 A. Pastyria et al.; Published by the Institute of Molecular Biology and Genetics, NAS of Ukraine on behalf of Biopolymers and Cell. This is an Open Access article distributed under the terms of the Creative Commons Attribution License (http://creativecommons.org/licenses/by/4.0/), which permits unrestricted reuse, distribution, and reproduction in any medium, provided the original work is properly cited 
Ukraine, the emergence of vvIBDV was registered in 2000 [2, 3, 4]. Molecular mechanisms of emergence of new IBDV strains include mutations in hypervariable region of VP2 gene. The virus replicates in immature B-lymphocytes that develop in bursa of Fabricius, which leads to immunosuppression of infected animals $[5,6,7]$.

The infectious bursal disease occurs primarily in poultry-producing areas thus leads to significant economic losses. IBDV is highly variable, that's why new virus strains with different level of virulence appear. Therefore, to control IBDV many different types of vaccines have been developed. They include live attenuated, inactivated, immune complex, vectored, DNA vaccine and ex. [1,8]. Live vaccines provide the best level of defense against IBD, so they are used in most of poultry farms in Ukraine [4, 8]. About 15 different live attenuated vaccines have been registered in Ukraine. They can be classified as mild, intermediate and intermediate-plus vaccines based on the level of attenuation and residual virulence for SPF chickens $[8,9]$. The intermediate-plus vaccines are regularly applied to protect chickens against vvIBDV challenges, while mild and intermediate vaccines are used for protection against classical strains of the virus. The choice of vaccine depends on type of virus that circulates in particular farm. Therefore, characterization of field isolates is required for proper vaccination.

Several approaches have been developed to the classify IBDV strains. Most of them are based on the nucleotide sequence analyses of VP2 gene, which encodes the main virus capsid protein $[5,9,10]$. The most efficient methods for diagnostics, molecular characterization and differentiation of IBDV field isolates include RT-PCR and restriction fragment length polymorphism (RFLP), nucleotide sequence analysis, and quantitative real time RT-PCR (qRT-PCR) [4, 5, 10].

The aim of the study was to characterize restriction profile of IBDV vaccine strains and field isolates, detected in Ukraine and to differentiate vaccine and field strains using restriction analysis.

\section{Materials and Methods}

During the study 120 samples of bursa tissues taken from chickens from 16 farms in 10 regions of Ukraine, which include Kyiv, Cherkasy, Lviv, Vinnytsia, Volyn, Dnipropetrovsk, Luhansk, Ternopil, Kharkiv and Crimea have been analyzed.

Vaccine strains used in study include mild (228E, GM97, MB/20) intermediate (V877, $\mathrm{MB} / 5$, Winterfield-2512) and intermediate-plus (MB, MB/3).

The RNA from vaccines and bursa tissues was extracted with the use of commercial kit Ribo-sorb ("Amplisens", Russia) according to the manufacturer's instruction. The obtained RNA has been used for the reverse transcription using the "Reverta" ("Amplisens", Russia) Reverse Transcription Kit. The obtained cDNA have been used for PCR reaction. For nested PCR two pairs of oligonucleotide primers have been used designated Bur1F (5'-TCACCGTC CTCAGCTTAC-3'), Bur1R (5'-TCAGGATT TGGGATCAGC-3'), Bur2F (5'-CGCTATAGC GCTTGACCCAAAAA-3'), Bur2R (5'-CTC ACCCCAGCGACCGTAACGACG-3'). PCR conditions were described previously by Borodavka et al [4]. The amplification products have been electrophoretically separated 
in the $1,5 \%$ agarose gel stained with the ethidium bromide and visualized by an ultraviolet transillumination. For the differentiation of IBDV vaccine strains and field isolates the obtained PCR products have been analyzed by digestion with restriction endonucleases MvaI, MboI, SspI, BspMI, SacI, BstEII ("Thermo", USA) as recommended by a supplier.

\section{Results and Discussion}

During the study RNA of IBDV has been detected in 75 of total 120 analyzed samples of organs taken from infected birds.

Most of the current research of IBDV aimed to determine the nucleotide sequence of the VP2 gene of different strains $[5,10]$. Comparing the sequences of vaccine and field isolates makes it possible to determine virus strain, but such research takes long time and requires big expenses. In terms of speed of diagnosis, we considered it appropriate to use restriction analysis as a method of differencing strains because it allows to quickly and accurately detect the difference between the vaccine and field virus strains by specific restriction sites.

Results of restriction analysis of strains 228E, GM97, V877 and MB correlate with previously described data by Borodavka et. al [4].
Restriction sites for strains MB/20, MB/5, MB/3 and Winterfield-2512 have been described for the first time.

Restriction profile of strain $\mathrm{MB} / 20$ was similar to that of strains 228E and GM97, and characterized by the presence of sites SacI, MvaI and MboI.

Strains V877 and MB/5 belonging to the group of intermediate vaccine strains, characterized by the presence of restriction sites for enzymes BstEII, MboI, SacI and MvaI.

For strain $\mathrm{MB} / 35$ restriction sites were identified for all restriction endonucleases used in the study, except for SacI. This restriction profile was similar to the previously described strain MB [4]. Cleavage of obtained amplicons of strains $\mathrm{MB} / 3$ and $\mathrm{MB}$ by SspI indicates that they have been attenuated from vvIBDV strains. Amplicons of $\mathrm{MB} / 3$ and $\mathrm{MB}$ strains have been also cleaved by BspMI enzyme. This restriction site have not been shown for other vaccine strains. Detection of BstEII restriction site in amplicons of vaccine strains $\mathrm{MB}$ and $\mathrm{MB} / 3$ can be used for differentiation from field vvIBDV.

Strain Winterfield-2512 have been characterized by a unique set of restriction sites, different from all other vaccine strained used

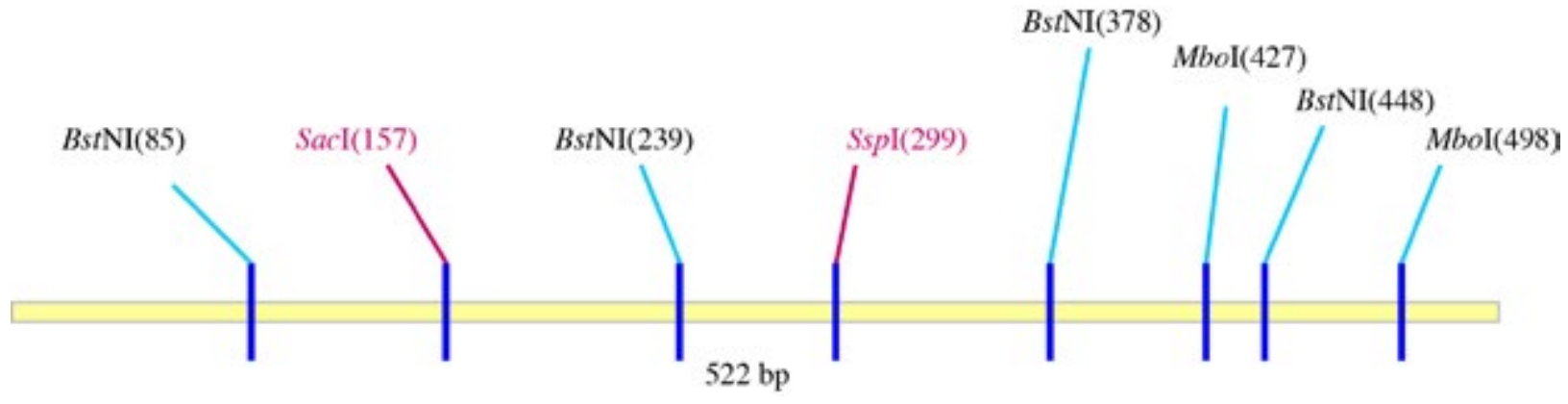

Fig. 1. Restriction map of VP2 gene of Winterfield-2512 strain. 
Table 1. Results of restriction analyses of VP2 gene of vaccine strains and vvIBDV strain UK661

\begin{tabular}{|c|c|c|c|c|c|c|}
\hline \multirow{2}{*}{ IBDV strain } & \multicolumn{6}{|c|}{ Resriction enzyme and length of restriction fragments (nt) } \\
\hline & Bsp MI & SacI & Ssp I & BstEII & $B s t \mathrm{NI} / M v a \mathrm{I}$ & MboI \\
\hline MB & $102+450$ & - & $326+226$ & $257+295$ & $475+77$ & $413+71+41+27$ \\
\hline V877 & _- & $184+368$ & - & $257+295$ & $230+210+112$ & $270+150+132$ \\
\hline UK661 & $102+450$ & - & $326+226$ & - & $475+77$ & $413+62+50+27$ \\
\hline GM97 & - & $184+368$ & - & - & $475+77$ & $413+62+50+27$ \\
\hline $228 \mathrm{E}$ & - & $184+368$ & - & - & $475+77$ & $413+62+50+27$ \\
\hline $\mathrm{MB} / 20$ & - & $184+368$ & - & - & $475+77$ & $413+62+50+27$ \\
\hline $\mathrm{MB} / 3$ & $102+450$ & - & $326+226$ & $257+295$ & $475+77$ & $413+71+41+27$ \\
\hline $\mathrm{MB} / 5$ & - & $184+368$ & - & $257+295$ & $230+210+112$ & $270+150+132$ \\
\hline Winterfield-2512 & & $169+383$ & $314+238$ & & $186+139+82+80+72$ & $452+71+29$ \\
\hline
\end{tabular}

in the study. Restriction map for this strain have not been previously described. MboI, SacI, MvaI BstNI and SspI restriction sites have been detected (Fig. 1). Simultaneous presence of restriction sites SacI and SspI have been shown. These restriction sites are considered to be markers of classical and vvIBDV strains respectively $[4,5,9]$.

Vaccine strains belonging to one group by the level of attenuation have been characterized by similar restriction profile (tab. 1).

Data obtained from restriction analyses of vaccine strains have been used for differentiation of detected virus isolates.

Thus, it was shown that 38 virus isolates had restriction profile similar to vaccine strains V877 and MB/. 25 identified isolates were similar to strains GM97, 228E and MB/20, while 8 have the same restriction sites as the strains of $\mathrm{MB}$ and $\mathrm{MB} / 3$ (Fig. 2).

For four analyzed virus isolates restricrion profile had been similar to reference vvIBDV strain UK661. These four isolates differ from intermediate plus vsccine strain in BstEII restriction site. Unlike the vaccine strains $\mathrm{MB}$ and MB/3 BstEII have not been shown (fig. 3)

\section{Conclusion}

We have described restriction profile of eight vaccine strains used in Ukraine and found that strains with the same level of residual virulence have similar restriction sites. However, for strain Winterfield-2512 unique restriction profile have been described that was different from all vaccine strains used in the study.

Based on restriction analyses for most of the analyzed virus isolates vaccine origin have been shown. These results show that tissue samples have been taken from vaccinated birds.

However for 4 isolates restriction sites similar to vvIDBV strain have been identified. This indicates that these isolates originated from field vvIBDV strains. Identification of

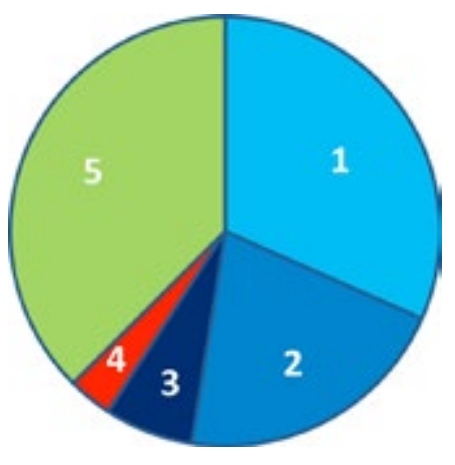

Fig. 2. Results of detection IBDV in bursa tissues samples: 1 vaccine strains V877 and $\mathrm{MB} / 5 ; 2$ - vaccine strains GM97, 228E and $\mathrm{MB} / 20$; 3 - vaccine strains $\mathrm{MB}$ and MB/3; 4 - vvIBDV; 5 - virus undetected. 


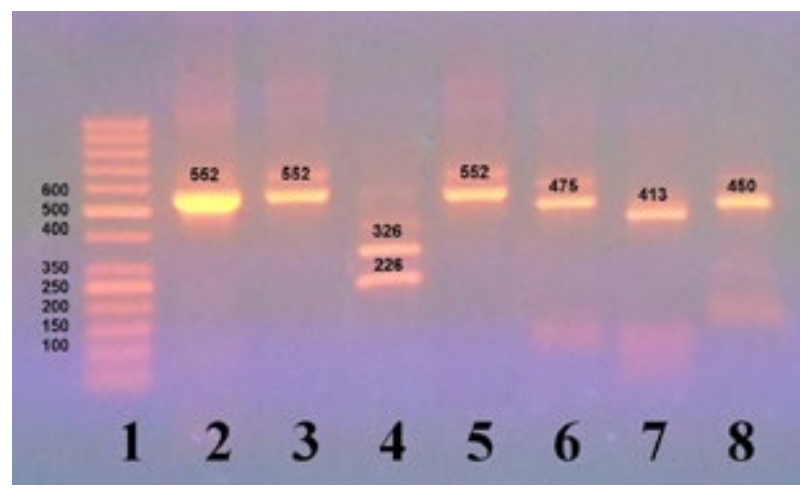

Fig. 3. Agarose gel electrophoresis of DNA fragments of obtained amplicons after digestion with restriction enzymes SacI, SspI, BstEII, MvaI, MboI, BspMI. Lanes: 1 - DNA size markers, 50 bp (Thermo). 2- amplicon, very virulent IBDV; 3- after digestion with SacI; 4 - after digestion with SspI; 5 - after digestion with BstEII; 6 after digestion with $\mathrm{MvaI} ; 7$ - after digestion with MboI; 8 - after digestion with BspMI.

vvIBDV shows a disadvantaged situation on the farm concerning Gumboro disease.

\section{REFERENCES:}

1. Diseases of poultry 12th edition. Ed Saif YM. Blackwell Publishing, 2008. 1352 p.

2. Aliyu HB, Sa'idu L, Jamilu A, Andamin AD, Akpavie $S O$. Outbreaks of virulent infectious bursal disease in flocks of battery cage brooding system of commercial chickens. J Vet Med. 2016;2016:8182160.

3. Berg TP. Acute infectious bursal disease in poultry: a review. Avian Pathol. 2000;29(3):175-94.

4. Borodavka O, Deryabin O, Sobko I, Polischuk V. Differentiation of infectious bursal disease viruses using RT-PCR and restriction analysis of obtained amplicons. Vestn Kiev Nats Univ Tarasa Shevchenko: Biol. 2008; 1(51):18-21.

5. Jackwood DJ. Recent trends in the molecular diagnosis of infectious bursal disease viruses. Anim Health Res Rev. 2004;5(2):313-6.

6. Sharma JM, Kim IJ, Rautenschlein S, Yeh HY. Infectious bursal disease virus of chickens: pathogenesis and immunosuppression. Dev Comp Immunol. 2000;24(2-3):223-35.
7. Wang S, Teng Q, Jia L, Sun $X$, Wu Y, Zhou J. Infectious bursal disease virus influences the transcription of chicken $\gamma \mathrm{c}$ and $\gamma \mathrm{c}$ family cytokines during infection. PLoS One. 2014;9(1):e84503.

8. Müller H, Mundt E, Eterradossi N, Islam MR. Current status of vaccines against infectious bursal disease. Avian Pathol. 2012;41(2):133-9.

9. Jackwood DJ, Sommer-Wagner SE. Detection and characterization of infectious bursal disease viruses in broilers at processing. Prev Vet Med. 2010;97(1): 45-50.

10. Mawgod SA, Arafa AS, Hussein HA. Molecular genotyping of the infectious bursal disease virus (IBDV) isolated from Broiler Flocks in Egypt. Int $J$ Vet Sci Med. 2014; 2(1):46-52.

\section{Диференіювання штамів вірусу інфекційної бурсальної хвороби виявлених в Україні методом рестрикційного аналізу}

А. С. Пастиря, І. О. Собко, В. П. Поліщук

Вірус інфекційної бурсальної хвороби (ІБХ) став актуальним для птахівництва 3 моменту появи високовірулентних штамів в середині 80-pp XX ст. Вони призводять до імуносупресивного стану тварин та високої смертності. 3 огляду на велику різноманітність вакцин, необхідною $є$ харакетристика польових ізолятів, виявлених у господарстві. Мета. охарактеризувати та диференціювати вакцинні та польові штами вірусу за допомогою методу рестрикційного аналізу. Методи. Виділення РНК здійснювали сорбційним методом, здійснювали постановку зворотної транскрипції та ПЛР із використанням специфічних праймерів до гену VP2. Отримані амплікони піддавали рестрикції MvaI, MboI, SspI, BspMI, SacI, BstEII. Результати. У роботі було охарактеризовано рестрикційний профіль 8 вакцинних штамів та проаналізовано 120 зразків бурс відібраних від уражених вірусом ІБХ птахів. Більшість проаналізованих ізолятів за рестрикційним профілем були подібними до вакцинних штамів. Вакцинні штами, що належали до однієї групи за рівнем атенуації мали одинаковий рестрикціний профіль. Для чотирьох було показано наявність сайтів SspI та відсутність сайту BstEII, що дає підставу віднести їх до високовірулентих штамів вірусу ІБХ. Висновок. Рестрикційний аналіз дає змогу диферен- 
ціювати вакцинні та польові ізоляти вірусу ІБХ. Даний підхід можна використовувати для моніторингу ситуації на господарстві за даним збудником.

К л юч о в і с л о в а: вірус ІБХ, польові штами, високовірулентні штами, рестрикційний аналіз.

\section{Дифференциация штаммов вируса инфекционной бурсальной болезни выявленных в Украине методом рестрикционного анализа}

\section{А. С. Пастыря, И. А. Собко, В. П. Полищук}

Вирус инфекционной бурсальной болезни (ИББ) стал актуальным для птицеводства с момента появления высоковирулентных штаммов в середине 80-гг ХХ в. Они приводят к иммуносупрессивном состоянию животных и высокой смертности. Учитывая большое разнообразие вакцин, необходима харакетристики полевых изолятов, выявленных в хозяйстве. Цель. охарактеризовать и дифференцировать вакцинные и полевые штаммы вируса с помощью метода рестрикционного анализа. Методы. РНК с образцов эктрагировали сорбционным методом, осуществляли поста- новку обратной транскрипции и ПЦР с использованием специфических праймеров к гену VP2. Полученные ампликоны подвергали рестрикции MvaI, MboI, SspI, BspMI, SacI, BstEII. Результаты. В работе были охарактеризованы рестрикционные профили 8 вакцинных штаммов и проанализированы 120 образцов бурс отобранных от пораженных вирусом ИБХ птиц. Большинство проанализированных изолятов за рестрикционым профилем были подобны вакцинным штаммам. Вакцинные штаммы, принадлежащие к одной группе по уровню аттенуации имели одинаковый рестрикционный профиль. Для четырех изолятов было показано наличие сайтов SspI и отсутствие сайта BstEII, что дает основание отнести их к высоковирулентым штаммам вируса ИББ. Выводы. Рестрикционный анализ позволяет дифференцировать вакцинные и полевые изоляты вируса ИББ. Данный подход можно использовать для мониторинга ситуации в хозяйстве по данному возбудителю.

К л ю ч е в ы е с л о в а: вирус ИББ, полевые штаммы, высоковирулентные штаммы, рестрикционный анализ.

Received 28.11.2016 